\title{
Amantichitinum ursilacus gen. nov., sp. nov., a chitin-degrading bacterium isolated from soil
}

\author{
Correspondence \\ Steffen Rupp \\ steffen.rupp@igb.fraunhofer.de
}

\author{
Karin S. Moß, ${ }^{1} \dagger$ Stefan C. Hartmann, ${ }^{1} \dagger$ Isabell Müller, ${ }^{2}$ Christina Fritz, ${ }^{2}$ \\ Sven Krügener, ${ }^{2}$ Susanne Zibek, ${ }^{2}$ Thomas Hirth ${ }^{1,2}$ and Steffen Rupp ${ }^{2}$ \\ ${ }^{1}$ Institute for Interfacial Engineering, University of Stuttgart, Nobelstraße 12, 70569 Stuttgart, \\ Germany \\ ${ }^{2}$ Fraunhofer Institute for Interfacial Engineering and Biotechnology, Nobelstraße 12, \\ 70569 Stuttgart, Germany
}

Chitin is the second most abundant polymer on earth, synthesized for use as structural scaffold by a variety of organisms including fungi, crustaceans and insects (Patil et al., 2000). Due to its omnipresence, many organisms are able to degrade chitin and use it as a carbon and energy source in metabolic processes (Campbell \& Williams, 1951). Habitats characterized by a natural enrichment of chitinous polymer, such as ant hills and other agglomerations of arthropoda, are more likely to harbour chitinolytic micro-organisms than other habitats. Therefore, screening for chitin-metabolizing micro-organisms in such habitats is highly promising. During a research project focused on the identification and characterization of new chitinolytic bacteria for use in industrial processes, strain IGB- $41^{\mathrm{T}}$ was isolated from a soil sample taken near Stuttgart, Germany.

A soil sample with a temperature of $18{ }^{\circ} \mathrm{C}$ was taken from an abandoned ant hill located near Lake Bärensee in

†These authors contributed equally to this work.

The GenBank/EMBL/DDBJ accession number for the 16S rRNA gene sequence of Amantichitinum ursilacus IGB- $41^{\top}$ is FN994890.

Two supplementary figures, a supplementary table and a sequence alignment are available with the online version of this paper.
Stuttgart, Germany. Chitinolytic organisms were enriched by sequential use of different media with chitin of rising complexity. In a first and second step, acidic pretreated chitin was used as carbon source, which in the third step was supplemented with protein-free milled chitin. The latter was the sole carbon source for the fourth culture step. Three grams of the soil sample were transferred into $100 \mathrm{ml}$ screening medium ( $\mathrm{pH} 4.2)$ containing $0.05 \mathrm{M}$ potassium phosphate, $5 \mathrm{mg} \mathrm{Ca}\left(\mathrm{NO}_{3}\right)_{2} \cdot 4 \mathrm{H}_{2} \mathrm{O} \mathrm{l}^{-1}$, $20 \mathrm{mg} \mathrm{MgSO}_{4} \cdot 7 \mathrm{H}_{2} \mathrm{O} \mathrm{l}{ }^{-1}, 100 \mathrm{mg}\left(\mathrm{NH}_{4}\right)_{2} \mathrm{SO}_{4} \mathrm{l}^{-1}, 1 \mathrm{mg}$ $\mathrm{Fe}(\mathrm{III}) \mathrm{NH}_{4}$-citrate $\mathrm{l}^{-1}, 100 \mu \mathrm{g} \mathrm{ZnSO}_{4} \cdot 7 \mathrm{H}_{2} \mathrm{O} \mathrm{l}^{-1}, 30 \mu \mathrm{g}$ $\mathrm{MnCl}_{2} .4 \mathrm{H}_{2} \mathrm{Ol}^{-1}, \quad 300 \mu \mathrm{g} \mathrm{H}_{3} \mathrm{BO}_{3} \mathrm{l}^{-1}, 200 \mu \mathrm{g} \mathrm{CoCl}_{2}$. $6 \mathrm{H}_{2} \mathrm{Ol}^{-1}, 10 \mu \mathrm{g} \mathrm{CuCl}_{2} \cdot 2 \mathrm{H}_{2} \mathrm{O} \mathrm{l}^{-1}, 20 \mu \mathrm{g} \mathrm{NiCl}_{2} \cdot 6 \mathrm{H}_{2} \mathrm{O} \mathrm{l}^{-1}$, $30 \mu \mathrm{g} \mathrm{Na} \mathrm{MoO}_{4} \cdot 2 \mathrm{H}_{2} \mathrm{O} \mathrm{l}^{-1}, 25 \mathrm{mg}$ tryptone $\mathrm{l}^{-1}, 12.5 \mathrm{mg}$ yeast extract $\mathrm{l}^{-1}, 25 \mathrm{mg} \mathrm{NaCl} \mathrm{l}{ }^{-1}$ and $0.5 \mathrm{~g}$ wet mass colloidal chitin $1^{-1}$. The suspension was incubated at $20{ }^{\circ} \mathrm{C}$. After 10 days, a $10 \mathrm{ml}$ aliquot of the suspension was added to $90 \mathrm{ml}$ fresh culture medium. This procedure was repeated twice with tryptone, yeast extract and $\mathrm{NaCl}$ omitted and $1 \mathrm{~g}$ chitin (Senn Chemicals) added for the third step. In a fourth step, colloidal chitin was also omitted.

The micro-organism suspension was diluted $1: 10^{6}$, spread on Luria-Bertani (LB)-agar pH 4.2 and incubated for 5 days at $20{ }^{\circ} \mathrm{C}$. Morphologically distinguishable colonies 
were purified by transfer onto new plates for repeated incubation under equivalent conditions.

The basic medium for growth determination was modified $\mathrm{LB}\left(\mathrm{LB}_{\text {mod }}\right)$ containing $10 \mathrm{~g}$ tryptone $\mathrm{l}^{-1}$ and $5 \mathrm{~g}$ yeast extract $1^{-1} ; 2 \%$ agar, buffer or $\mathrm{NaCl}$ was added, if necessary. Growth at different temperatures was analysed on $\mathrm{LB}_{\text {mod }}$-agar plates at $\mathrm{pH} 6.85$ at temperatures between 4 and $40{ }^{\circ} \mathrm{C}\left(4,10,152025,30,35,37\right.$ and $\left.40{ }^{\circ} \mathrm{C}\right)$. For the determination of $\mathrm{pH}$-dependent growth, $\mathrm{LB}_{\text {mod }}$-agar plates were supplemented with either $0.05 \mathrm{M}$ citric acid/ $\mathrm{NaOH}$ or ammonium chloride/ammonia buffer to yield $\mathrm{pH}$ values between 4 and $10(\mathrm{pH} 4.14,4.85,5.73,6.61,6.98,8.19$ and 9.2). The final $\mathrm{pH}$ was determined prior to sterilization. Salt tolerance was determined by growth at $\mathrm{NaCl}$ concentrations between 0 and $4 \%(0,1,2,3$ and $4 \%)$. Growth was determined after 3,5 and 10 days and evaluated by colony size. Isolate IGB- $41^{\mathrm{T}}$ was maintained as glycerol stock ( $50 \%$, by vol.) at $-80{ }^{\circ} \mathrm{C}$.

Gram reaction was conducted as described by Bast (2001) with Lactobacillus plantarum and Escherichia coli as controls. Cell morphology was examined by light microscopy and scanning electron microscopy after fixation with glutaraldehyde and dehydration by sequential washing with rising ethanol concentrations.

Growth under anaerobic conditions, lysis by $\mathrm{KOH}$, aminopeptidase-, oxidase- and catalase activities as well as use or hydrolysis of different compounds such as adipate, citrate, malate, phenylacetate, gelatin, DNA, Tween 80 and starch were tested by the Deutsche Stammsammlung für Mikroorganismen und Zellkulturen (DSMZ, Braunschweig, Germany) according to standard procedures (Reddy et al., 2007).

For the determination of $\mathrm{G}+\mathrm{C}$ content, genomic DNA was purified according to the procedure of Cashion et al. (1977). DNA was hydrolysed and prepared for measurement according to the protocol of Mesbah et al. (1989). Analysis of G $+\mathrm{C}$ content was done by HPLC according to the methods of Tamaoka \& Komagata (1984) and Mesbah et al. (1989). The reaction was controlled with genomic DNA of Bacillus subtilis DSM 402 (43.5 mol\% $\mathrm{G}+\mathrm{C})$, Xanthomonas campestris DSM $3586^{\mathrm{T}}(65.1 \mathrm{~mol} \% \mathrm{G}+\mathrm{C})$ and Streptomyces violaceoruber DSM 40783 (72.1 mol\% $\mathrm{G}+\mathrm{C})$. The determination of $\mathrm{G}+\mathrm{C}$ content was performed in commission by the DSMZ.

DNA-DNA hybridization experiments were performed with isolate IGB-41 ${ }^{\mathrm{T}}$, Silvimonas amylolytica NBRC $103189^{\mathrm{T}}$, Silvimonas iriomotensis NBRC $103188^{\mathrm{T}}$ and Silvimonas terrae DSM $18233^{\mathrm{T}}$ by the DSMZ. DNA was isolated using the procedure of Cashion et al. (1977). DNA-DNA hybridization was carried out as previously described (Huß et al., 1983; De Ley et al., 1970) using a Cary 100 Bio UV-VIS-spectrophotometer equipped with a Peltierthermostat-regulated $6 \times 6$ multicell changer and a temperature controller with an in situ temperature probe (Varian). Results were obtained in $2 \times$ SSC, $5 \%$ formamide at $70{ }^{\circ} \mathrm{C}$.
Genomic DNA was isolated after mechanical cell disruption according to Ausubel et al. (1987). Nearly full-length 16S rRNA (1492 bp) of isolate IGB- $41^{\mathrm{T}}$ was amplified using standard PCR primers (for-16S: AGAGTTTGATCMTGGCTCAG; rev-16S: TACGGYTACCTTGTTACGACTT). PCR was performed under the following cycling conditions: initial denaturation at $94{ }^{\circ} \mathrm{C}$ for $3 \mathrm{~min}, 94{ }^{\circ} \mathrm{C}$ for $30 \mathrm{~s}$, annealing for $45 \mathrm{~s}$ at $56{ }^{\circ} \mathrm{C}$ and elongation at $72{ }^{\circ} \mathrm{C}$ for $2 \mathrm{~min}$. After 30 cycles, final elongation was allowed for $10 \mathrm{~min}$ at $72{ }^{\circ} \mathrm{C}$. Phylogenetic trees were reconstructed based on 16S rRNA using the ARB software package (Ludwig et al., 2004). 16S rRNA gene sequence quality of isolate IGB- $41^{\mathrm{T}}$ was checked for sequence anomalies as described by Ashelford et al. (2006). $16 \mathrm{~S}$ rRNA sequences were aligned locally using CLUSTAL_X v2.1 (Larkin et al., 2007). The resulting alignment was used for tree reconstruction and is available as a supplementary FASTA file in IJSEM Online. The neighbour-joining algorithm (Saitou \& Nei, 1987) with Jukes-Cantor correction was applied to reconstruct a phylogenetic tree with 1000-fold resampling. Tree topology was evaluated using Randomized Axelerated Maximum-likelihood RAxML v7.0.3 implemented into ARB (Stamatakis, 2006).

Fatty acid methyl esters were obtained from $40 \mathrm{mg}$ cell mass, grown on trypticase soy broth agar (TSA) for two days at $28{ }^{\circ} \mathrm{C}$. Cells were scraped from Petri dishes followed by saponification, methylation and extraction using minor modifications of the method described by Miller (1982) and Kuykendall et al. (1988). The fatty acid methyl ester mixtures were separated by the DSMZ using the Sherlock Microbial identification System (MIS) (MIDI, Microbial ID).

Polar lipid analysis and analysis of respiratory quinones was performed by the Identification Service of the DSMZ and Dr B. J. Tindall, DSMZ. Cells were grown in $\mathrm{LB}_{\text {mod }}$ without $\mathrm{NaCl}$ at $25{ }^{\circ} \mathrm{C}$ prior to analysis. Lipid extraction was done from $100 \mathrm{mg}$ of freeze-dried cells using the two stage method described by Tindall (1990a, b). Respiratory quinones were extracted using methanol: hexane $(2: 1$, by vol.) followed by phase separation into hexane (Tindall, 1990a, b). Separation of lipoquinones into their different classes was conducted by TLC on silica gel (MachereyNagel) using hexane: tert-butylmethylether $[9: 1(\mathrm{v} / \mathrm{v})]$ as the solvent. UV-absorbing bands corresponding to different quinone classes were further analysed by HPLC. This step was carried out on a LDC Analytical (Thermo Separation Products) HPLC fitted with a reverse phase column (Macherey-Nagel, $2 \mathrm{~mm} \times 125 \mathrm{~mm}, 3 \mu \mathrm{m}$, RP18) using methanol:heptane $[9: 1(\mathrm{v} / \mathrm{v})]$ as the eluent. Respiratory lipoquinones were detected at $269 \mathrm{~nm}$.

Polar lipids were extracted by adjusting the remaining methanol: $0.3 \%$ aqueous $\mathrm{NaCl}$ phase to give a chloroform: methanol: $0.3 \%$ aqueous $\mathrm{NaCl}$ mixture $1: 2: 0.8$ (by volume). The extraction solvent was stirred overnight and cell debris was pelleted by centrifugation. Polar lipids were recovered into the chloroform phase by adjusting the 
chloroform:methanol: $0.3 \%$ aqueous $\mathrm{NaCl}$ mixture to a ratio of $1: 1: 0.9$ (by volume) and separated by two dimensional silica gel TLC (Macherey-Nagel). The first direction was developed in chloroform:methanol: water $(65: 25: 4$, by volume) and the second in chloroform: methanol: acetic acid:water ( $80: 12: 15: 4$, by volume). Total lipid material and specific functional groups were detected using dodecamolybdophosphoric acid (total lipids), Zinzadze reagent (phosphate), ninhydrin (free amino groups), periodate-Schiff ( $\alpha$-glycols), Dragendorff (quaternary nitrogen) and $\alpha$-naphthol-sulphuric acid (glycolipids) (Tindall et al., 2007).

Isolate IGB- $41^{\mathrm{T}}$ was found to be a representative of Gramnegative, rod-shaped (see Fig. S1a, b), motile and facultatively anaerobic bacteria with Q-8 found as the only detectable isoprenoid quinone.

Phylogenetic analysis revealed that isolate IGB- $41^{\mathrm{T}}$ belonged to the class Betaproteobacteria. Clustering was always observed within the family Neisseriaceae together with Silvimonas amylolytica NBRC $103189^{\mathrm{T}}$, Silvimonas iriomotensis NBRC $103188^{\mathrm{T}}$ and Silvimonas terrae KM- $45^{\mathrm{T}}$ as the phylogenetically closest relatives with 96.7, 96.6 and $96.1 \%$ sequence similarity, respectively. The divergent branching pattern between isolate IGB- $41^{\mathrm{T}}$ and the inner cluster of species of the genus Silvimonas was highly reproducible with solid bootstrap recovery using the neighbour-joining algorithm. This topology was further confirmed using RAxML (Fig. 1). Jeongeupia naejangsanensis BIO-TAS4-2 ${ }^{\mathrm{T}}$, Andreprevotia lacus GFC- $1^{\mathrm{T}}$ and Andreprevotia chitinilytica $\mathrm{JS} 11-7^{\mathrm{T}}$ formed an intrinsically stable sibling cluster to the cluster including isolate IGB- $41^{\mathrm{T}}$ and exhibited sequence similarities of only 93.3, 93.2 and $93.0 \%$, respectively, to strain IGB- $41^{\mathrm{T}}$. The level of sequence similarity observed between IGB- $41^{\mathrm{T}}$ and its phylogenetically closest neighbour Silvimonas amylolytica NBRC $103189^{\mathrm{T}}$ was significantly below the interspecies level of sequence similarity of recognized species of the genus
Silvimonas which is in a range of $98.8-99.2 \%$. This suggests that strain IGB- $41^{\mathrm{T}}$ forms an independent phylum in proximity to species of the genus Silvimonas.

The level of DNA-DNA relatedness as determined by DNA-DNA hybridization between isolate IGB- $41^{\mathrm{T}}$ and the type strains of Silvimonas amylolytica, Silvimonas iriomotensis and Silvimonas terrae was found with values of 18.4, 13.1 and $9.9 \%$, respectively. This is far below the proposed threshold for species delineation of $70 \%$ (Wayne et al., 1987), which indicates that strain IGB- $41^{\mathrm{T}}$ is a representative of a new genus and not a member of the genus Silvimonas.

The predominant fatty acids of strain IGB- $41^{\mathrm{T}}$ were identified as $\mathrm{C}_{16: 0}(26.1 \%)$, summed feature 3 (iso- $\mathrm{C}_{15: 0}$ 2-OH and/or $\left.\mathrm{C}_{16: 1} \omega 7 c\right)(26.1 \%)$ and $\mathrm{C}_{18: 1} \omega 7 c(22.4 \%)$. Differences between the fatty acid composition of species of the genus Silvimonas and isolate IGB- $41^{\mathrm{T}}$ were evident, especially for short-chain and hydroxylated fatty acids. In this comparison, strain IGB- $41^{\mathrm{T}}$ was the only representative with the metabolic compounds $\mathrm{C}_{14: 0} 2-\mathrm{OH}(2.2 \%), \mathrm{C}_{15: 0}$ $(1.4 \%)$ and $\mathrm{C}_{18: 1} 2-\mathrm{OH}(1.5 \%)$ (Table S1), whereas the other fatty acids were found with similar patterns and concentration ranges. Therefore, to further discriminate between the organisms, we performed polar lipid analysis.

Two dimensional TLC revealed fundamental differences between the polar lipid cell membrane composition of strains IGB-41 $1^{\mathrm{T}}$ and Silvimonas amylolytica NBRC $103189^{\mathrm{T}}$. Glycolipids were found in Silvimonas amylolytica NBRC $103189^{\mathrm{T}}$, while they were absent in isolate IGB- $41^{\mathrm{T}}$. Strain IGB- $41^{\mathrm{T}}$ was unique in harbouring phosphoaminolipids, aminolipids and glycoaminolipids. This underlines the phylogenetic divergence between strain $\mathrm{IGB}-41^{\mathrm{T}}$ and Silvimonas amylolytica NBRC $103189^{\mathrm{T}}$. Both strains gave a positive result for diphosphatidylglycerol, phosphatidylglycerol, phosphatidylethanolamine and phospholipids. Quantitative consideration revealed higher contents of phosphatidylethanolamine for Silvimonas amylolytica NBRC $103189^{\mathrm{T}}$ than for strain IGB- $41^{\mathrm{T}}$ as can be deduced

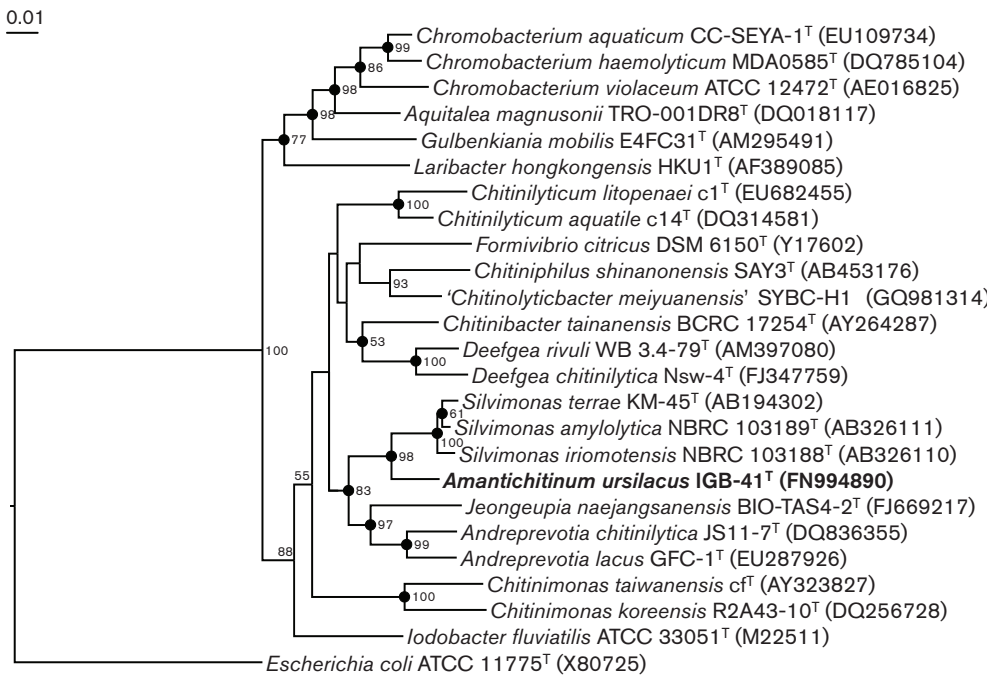

Fig. 1. Rooted neighbour-joining tree showing phylogenetically close neighbours of isolate IGB $-41^{\top}$ within the family Neisseriaceae. Filled circles indicate branching patterns also recovered using RAxML. Bootstrap values $\geqslant 50 \%$ are shown. Bar, 1 nt substitution per 100 bases. 
Table 1. Differential characteristics of strain IGB- $41^{\top}$ and the closest phylogenetic neighbours

Taxa: 1, Amantichitinum ursilacus IGB-41 ${ }^{\mathrm{T}}$; 2, Silvimonas amylolytica NBRC $103189^{\mathrm{T}}$ (Muramatsu et al., 2010); 3, Silvimonas iriomotensis NBRC 103188 ${ }^{\mathrm{T}}$ (Muramatsu et al., 2010); 4, Silvimonas terrae KM-45 ${ }^{\mathrm{T}}$ (Yang et al., 2005; Muramatsu et al., 2010); 5, Jeongeupia naejangsanensis BIO-TAS4-2 ${ }^{\mathrm{T}}$ (Yoon et al., 2010); 6, Andreprevotia chitinilytica JS11- $7^{\mathrm{T}}$ (Weon et al., 2007); 7, Andreprevotia lacus GFC-1 ${ }^{\mathrm{T}}$ (Sheu et al., 2009). (+), weakly positive; +, positive; -, negative; ND, not determined. All strains are rod-shaped.

\begin{tabular}{|c|c|c|c|c|c|c|c|}
\hline Characteristic & 1 & 2 & 3 & 4 & 5 & 6 & 7 \\
\hline Cell size $(\mu \mathrm{m})$ & $0.7-0.8 \times 1.5-3.0$ & $0.4-0.5 \times 0.8-1.3$ & $0.3-0.5 \times 1.0-1.5$ & $0.5-0.8 \times 1.3-2.0$ & $0.3-0.7 \times 0.7-2.5$ & $0.7-0.9 \times 2.0-3.0$ & $0.5 \times 1.0-2.0$ \\
\hline Anaerobic growth & + & + & + & + & + & - & - \\
\hline $\mathrm{pH}$ range & $6-9$ & $4-9$ & $4-9$ & $6-8$ & $\geqslant 5$ & $5-8$ & $7-9$ \\
\hline pH optimum & 7 & 4 & 4 & 7 & $7-8$ & $6-7$ & 7 \\
\hline Temp. range $\left({ }^{\circ} \mathrm{C}\right)$ & $10-35$ & $5-40$ & $5-40$ & $15-40$ & $10-50$ & $5-35$ & $15-37$ \\
\hline Temp. optimum $\left({ }^{\circ} \mathrm{C}\right)$ & $20-25$ & 30 & 30 & $25-30$ & 30 & 28 & 30 \\
\hline $\mathrm{NaCl}$ tolerance $(\mathrm{w} / \mathrm{v}, \%)$ & 0 & $0-1$ & $0-3$ & $0-2$ & $0-3.0$ & $0-2$ & $0-1$ \\
\hline $\begin{array}{l}\text { Optimal } \mathrm{NaCl} \text { Concentration } \\
(\mathrm{w} / \mathrm{v}, \%)\end{array}$ & 0 & 0 & 0 & ND & $0-1.0$ & $\mathrm{ND}$ & $0-0.5$ \\
\hline DNA G $+\mathrm{C}$ content $(\mathrm{mol} \%)$ & 61.5 & 57.5 & 59.9 & 58 & 63.8 & 62 & 63.0 \\
\hline Major quinone & Q-8 & Q-8 & Q-8 & Q-8 & Q-8 & Q-8 & $\mathrm{ND}$ \\
\hline Assimilation of mannose & - & + & + & + & + & $(+)$ & + \\
\hline \multicolumn{8}{|l|}{ Hydrolysis of } \\
\hline Chitin & + & - & - & $-\left(+^{\star}\right)$ & $\mathrm{ND}$ & - & + \\
\hline Gelatin & - & - & - & - & - & + & ND \\
\hline Aesculin & + & + & + & - & - & - & - \\
\hline DNA & - & - & - & + & $\mathrm{ND}$ & ND & $\mathrm{ND}$ \\
\hline
\end{tabular}

${ }^{*}$ According to original description. 
from the TLC data images given in a format defined by Tindall et al. (2010) (Fig. S2).

Further differences were observed in biochemical and physiological characteristics. Strain IGB- $41^{\mathrm{T}}$ was able to grow with $\mathrm{pH}$ values ranging from 6 to 9 . However, growth occured only in the absence of $\mathrm{NaCl}$. A growth temperature range from 10 to $35{ }^{\circ} \mathrm{C}$ with an optimum at $20-25{ }^{\circ} \mathrm{C}$ was observed. In contrast, species of the genus Silvimonas show growth at up to $40{ }^{\circ} \mathrm{C}$, are characterized by higher salt tolerance and are reported to be positive for mannose assimilation, while the latter was not found for isolate IGB- $41^{\mathrm{T}}$. Silvimonas terrae $\mathrm{KM}-45^{\mathrm{T}}$ has been reported to be positive for chitinolytic activity (Yang et al., 2005). However, this was not confirmed in a more recent study (Muramatsu et al., 2010) suggesting that none of the species of the genus Silvimonas known so far is positive for chitinolytic activity. Thus, strain IGB- $41^{\mathrm{T}}$ can be clearly distinguished from these species based on its chitinolytic and mannose-assimilating activities. The $\mathrm{G}+\mathrm{C}$ content of strain IGB- $41^{\mathrm{T}}$ was found to be $61.5 \mathrm{~mol} \%$ and this is outside the threshold of $57-60 \mathrm{~mol} \%$ given in the emended genus definition of Silvimonas produced by Muramatsu et al. (2010). Further fundamental differences between the strains discussed are summarized in Table 1.

According to the physiological data observed, the highly reproducible clustering of strain IGB- $41^{\mathrm{T}}$, which was never observed with species within the genus Silvimonas, and the assumptions on the assignment of new genera and species made in previous works (Stackebrandt \& Goebel, 1994; Wayne et al., 1987), we propose the assignment of isolate IGB- $41^{\mathrm{T}}$ to a new genus and a novel species. We suggest the name Amantichitinum ursilacus gen. nov., sp. nov. with isolate IGB- $41^{\mathrm{T}}$ as type strain.

\section{Description of Amantichitinum gen. nov.}

Amantichitinum [A.man.ti.chi'ti.num. L. part. adj. amans -antis loving; N.L. chitinum chitin; N.L. neut. n. Amantichitinum loving-chitin (bacterium)].

Cells of this genus are Gram-negative, motile, rod-shaped $(1.5-3.0 \mu \mathrm{m} \times 0.7-0.8 \mu \mathrm{m})$ and facultatively anaerobic. They occur singly or in pairs (Fig. S1). Colonies on $\mathrm{LB}_{\text {mod }}$ are milky white to beige, circular, convex and about $1 \mathrm{~mm}$ in diameter. Representatives are catalase- and oxidase-positive. The only detectable quinone is Q-8. Major fatty acids $(>10 \%)$ are $\mathrm{C}_{16: 0}$, summed feature 3 (comprising iso- $\mathrm{C}_{15: 0}$ 2-OH and/or $\mathrm{C}_{16: 1} \omega 7 c$ ) and $\mathrm{C}_{18: 1} \omega 7 c$. Based on 16S rRNA sequence analysis, Amantichitinum belongs to the Betaproteobacteria. The type species is Amantichitinum ursilacus.

\section{Description of Amantichitinum ursilacus sp. nov.}

Amantichitinum ursilacus [ur.si.la'cus. L. n. ursus $-i$ a bear; L. n. lacus a lake; N.L. gen. n. ursilacus of Bear Lake (Bärensee), a lake nearby Stuttgart, Germany, on the edge of which the strain was isolated].
Exhibits the following properties in addition to those given in the genus description. Growth is observed between 10 and $35{ }^{\circ} \mathrm{C}$ and at $\mathrm{pH}$ values of $6-9$ (optimum $\mathrm{pH}$ 7). Growth occurs in the absence of $\mathrm{NaCl}$. Gives a positive result in tests for nitrate reduction and acid formation from glucose. Hydrolyses aesculin, Tween 80, starch and chitin, but not gelatin or DNA. According to the API 50 $\mathrm{CH}$ panel, positive for fermentation of $\mathrm{L}$-arabinose, $\mathrm{D}$ ribose, DL-xylose, galactose, glucose, fructose, D-mannose, D-mannitol, $N$-acetylglucosamine, amygdalin, arbutin, aesculin, ferric citrate, salicin, D-cellobiose, D-maltose, starch, glycogen and D-arabitol. A weak reaction is observed for L-rhamnose, D-lactose (bovine), D-sucrose, gentiobiose and D-lyxose metabolism. The reactions for glycerol, erythritol, D-arabinose, D-adonitol, methyl $\beta$-Dxylopyranoside, L-sorbose, dulcitol, inositol, D-sorbitol, methyl $\alpha$-D-mannopyranoside, methyl $\alpha$-D-glucopyranoside, D-melibiose, D-trehalose, inulin, D-melezitose, Draffinose, xylitol, D-turanose, D-tagatose, D-fucose, Lfucose, L-arabitol, potassium gluconate, potassium-2-ketogluconate and potassium-5-ketoglucomate are negative. Assimilation of adipate, citrate, malate and phenylacetate is negative. The major fatty acids $(>5 \%)$ are $\mathrm{C}_{16: 0}(26.1 \%)$, summed feature 3 (iso- $\mathrm{C}_{15: 0} 2-\mathrm{OH}$ and/or $\mathrm{C}_{16: 1} \omega 7 c$ ) $(26.1 \%), \mathrm{C}_{18: 1} \omega 7 c(22.4 \%), \mathrm{C}_{17: 0}$ cyclo $(6.0 \%)$ and $\mathrm{C}_{14: 0}$ $(5.5 \%)$.

The type strain, IGB- $41^{\mathrm{T}}\left(=\right.$ DSM $23761^{\mathrm{T}}=$ CIP $\left.110167^{\mathrm{T}}\right)$, was isolated from soil from an abandoned ant hill located near lake Bärensee in Stuttgart, Germany. The DNA G +C content of the type strain is $61.5 \mathrm{~mol} \%$.

\section{Acknowledgements}

This work was granted by the Bundesministerium für Bildung und Forschung (BMBF) within the project 0313712 (Neue Enzyme und Verfahren zur Herstellung von biobasierten Produkten durch Integration von biotechnologischen und chemischen Verfahren BioSysPro). We thank Dr Susanne Verbarg and Dr Brian Tindall from the Deutsche Stammsammlung für Mikroorganismen und Zellkulturen (DSMZ; Braunschweig, Germany) for discussions and help with data interpretation. We further thank Dr Jörg Peplies (Ribocon, Bremen, Germany) for general discussions.

\section{References}

Ashelford, K. E., Chuzhanova, N. A., Fry, J. C., Jones, A. J. \& Weightman, A. J. (2006). New screening software shows that most recent large 16S rRNA gene clone libraries contain chimeras. Appl Environ Microbiol 72, 5734-5741.

Ausubel, F. M., Brent, R., Kingston, R. E., Moore, D. D., Seidman, J. G., Smith, J. A. \& Struhl, K. (editors) (1987). Current Protocols in Molecular Biology. New York: Green Publishing \& Wiley Interscience.

Bast, E. (2001). Mikrobiologische Methoden: Eine Einführung in grundlegende Arbeitstechniken. Heidelberg: Spektrum Akademischer Verlag GmbH.

Campbell, L. L. \& Williams, O. B. (1951). A study of chitindecomposing micro-organisms of marine origin. J Gen Microbiol 5 (Suppl.), 894-905. 
Cashion, P., Holder-Franklin, M. A., McCully, J. \& Franklin, M. (1977). A rapid method for the base ratio determination of bacterial DNA. Anal Biochem 81, 461-466.

De Ley, J., Cattoir, H. \& Reynaerts, A. (1970). The quantitative measurement of DNA hybridization from renaturation rates. Eur $J$ Biochem 12, 133-142.

Huß, V. A. R., Festl, H. \& Schleifer, K. H. (1983). Studies on the spectrophotometric determination of DNA hybridization from renaturation rates. Syst Appl Microbiol 4, 184-192.

Kuykendall, L. D., Roy, M. A., O’Neill, J. J. \& Devine, T. E. (1988). Fatty acids, antibiotic resistance, and deoxyribonucleic acid homology groups of Bradyrhizobium japonicum. Int J Syst Bacteriol 38, 358-361.

Larkin, M. A., Blackshields, G., Brown, N. P., Chenna, R., McGettigan, P. A., McWilliam, H., Valentin, F., Wallace, I. M., Wilm, A. \& other authors (2007). CLUSTAL W and CLUSTAL_X version 2.0. Bioinformatics 23, 2947-2948.

Ludwig, W., Strunk, O., Westram, R., Richter, L., Meier, H., Yadhukumar, Buchner, A., Lai, T., Steppi, S. \& other authors (2004). ARB: a software environment for sequence data. Nucleic Acids Res 32, 1363-1371.

Mesbah, M., Premachandran, U. \& Whitman, W. B. (1989). Precise measurement of the $\mathrm{G}+\mathrm{C}$ content of deoxyribonucleic acid by highperformance liquid chromatography. Int J Syst Bacteriol 39, 159-167.

Miller, L. T. (1982). Single derivatization method for routine analysis of bacterial whole-cell fatty acid methyl esters, including hydroxy acids. J Clin Microbiol 16, 584-586.

Muramatsu, Y., Suzuki, K. \& Nakagawa, Y. (2010). Silvimonas iriomotensis sp. nov. and Silvimonas amylolytica sp. nov., new members of the class Betaproteobacteria isolated from the subtropical zone in Japan. Int J Syst Evol Microbiol 60, 174-178.

Patil, R. S., Ghormade, V. \& Deshpande, M. V. (2000). Chitinolytic enzymes: an exploration. Enzyme Microb Technol 26, 473-483.

Reddy, C. A., Beveridge, T. J., Breznak, J. A., Snyder, L., Schmidt, T. M. \& Marzluf, G. A. (2007). Methods for General and Molecular Microbiology. Washington, DC: American Society for Microbiology.

Saitou, N. \& Nei, M. (1987). The neighbor-joining method: a new method for reconstructing phylogenetic trees. Mol Biol Evol 4, 406-425.

Sheu, S. Y., Chiu, T. F., Chou, J. H., Sheu, D. S., Arun, A. B., Young, C. C., Chen, C. A., Wang, J. T. \& Chen, W. M. (2009). Andreprevotia lacus sp. nov., isolated from a fish-culture pond. Int J Syst Evol Microbiol 59, 2482-2485.
Stackebrandt, E. \& Goebel, B. M. (1994). Taxonomic note: A place for DNA-DNA reassociation and 16S rRNA sequence analysis in the present species definition in bacteriology. Int J Syst Bacteriol 44, 846849 .

Stamatakis, A. (2006). RAxML-VI-HPC: maximum likelihood-based phylogenetic analyses with thousands of taxa and mixed models. Bioinformatics 22, 2688-2690.

Tamaoka, J. \& Komagata, K. (1984). Determination of DNA base composition by reversed-phase high-performance liquid chromatography. FEMS Microbiol Lett 25, 125-128.

Tindall, B. J. (1990a). A comparative study of the lipid composition of Halobacterium sacharovorum from various sources. Syst Appl Microbiol 13, 128-130.

Tindall, B. J. (1990b). Lipid composition of Halobacterium lacusprofundi. FEMS Microbiol Lett 66, 199-202.

Tindall, B. J., Sikorski, J., Smibert, R. M. \& Kreig, N. R. (2007). Phenotypic characterization and the principles of comparative systematics. In Methods for General and Molecular Microbiology, 3rd edn. pp. 330-393. Edited by C. A. Reddy, T. J. Beveridge, J. A. Breznak, G. A. Marzluf, T. M. Schmidt \& L. Snyder. Washington, DC, USA: American Society for Microbiology.

Tindall, B. J., Rosselló-Móra, R., Busse, H. J., Ludwig, W. \& Kämpfer, P. (2010). Notes on the characterization of prokaryote strains for taxonomic purposes. Int J Syst Evol Microbiol 60, 249-266.

Wayne, L. G., Brenner, D. J., Colwell, R. R., Grimont, P. A. D., Kandler, O., Krichevsky, M. I., Moore, L. H., Moore, W. E. C., Murray, R. G. E. \& other authors (1987). International Committee on Systematic Bacteriology. Report of the ad hoc committee on reconciliation of approaches to bacterial systematics. Int J Syst Bacteriol 37, 463-464.

Weon, H.-Y., Kim, B.-Y., Yoo, S.-H., Joa, J.-H., Kwon, S.-W. \& Kim, W.-G. (2007). Andreprevotia chitinilytica gen. nov., sp. nov., isolated from forest soil from Halla Mountain, Jeju Island, Korea. Int J Syst Evol Microbiol 57, 1572-1575.

Yang, H.-C., Im, W.-T., An, D.-S., Park, W. S., Kim, I. S. \& Lee, S.-T. (2005). Silvimonas terrae gen. nov., sp. nov., a novel chitin-degrading facultative anaerobe belonging to the 'Betaproteobacteria'. Int J Syst Evol Microbiol 55, 2329-2332.

Yoon, J. H., Choi, J. H., Kang, S. J., Choi, N. S., Lee, J. S. \& Song, J. J. (2010). Jeongeupia naejangsanensis gen. nov., sp. nov., a cellulosedegrading bacterium isolated from forest soil from Naejang Mountain in Korea. Int J Syst Evol Microbiol 60, 615-619. 